\title{
SPATIAL STRUCTURE OF A NATURAL MIXED TOPODEME OF SUBALPINE SORBUS TAXA
}

\author{
DUŠAN GÖMÖRY, DIANA KRAJMEROVÁ \\ Technical University in Zvolen, Faculty of Forestry \\ TG Masaryka 24, SK-960 53 Zvolen, Slovakia \\ e-mail: gomory@vsld.tuzvo.sk
}

(Received: August 6, 2007. Accepted: March 20, 2008)

\begin{abstract}
Spatial distribution and genetic variation of a population of Sorbus chamaemespilus (L.) Crantz and putative hybrids between $S$. chamaemespilus, S. aria and S. aucuparia growing in the nature reserve Skalná Alpa (central Slovakia) were studied. The analysis of spatial patterns using Ripley's $K$-function revealed a significant clustering of the adults of both $S$. chamaemespilus and hybrid taxa at distances up to $\sim 15 \mathrm{~m}$ and a strong affinity between both taxonomical groups, indicating similar ecological requirements. Bivariate point-pattern analysis considering cardinal direction showed that juvenile individuals of $S$. chamaemespilus are clustered around the adults up to the distance of $\sim 2 \mathrm{~m}$, whereas in hybrid taxa with larger and more dense crowns, juveniles are clustered at distances more than $\sim 3 \mathrm{~m}$ from the adults. The analysis of genetic variation in a subset of adult shrubs using 4 nuclear microsatellite loci revealed that unlike expected, there was no variation in $S$. chamaemespilus but several genotypes were found in the group of hybrid taxa. Implications for the reproduction system and conservation of the investigated taxa are discussed.
\end{abstract}

KEY WORDS: Sorbus L., spatial structure, apomixis, nuclear microsatellites, dispersal.

\section{INTRODUCTION}

The genus Sorbus L., just like the whole family Rosaceae, belongs to the most complicated plant taxa (Aldasoro et al. 1998; Nelson-Jones et al. 2002). Flora Europaea lists 113 Sorbus taxa of various ranks in Europe. Among them, there are five diploid species classified to different subgenera (Warburg and Kárpáti 1968): S. aucuparia L. (subgen. Sorbus), S. domestica L. (subgen. Cormus), S. torminalis (L.) Crantz (subgen. Torminaria), S. chamaemespilus (L.) Crantz (subgen. Chamaemespilus), and S. aria (L.) Crantz (subgen. Aria). These species are generally recognized and occupy relatively large ranges. Moreover, there is a plenty of local, mostly stenoendemic taxa of hybridogenous origin. Most of them are supposed to have originated from the hybridization between $S$. aria sensu lato and S. chamaemespilus, S. torminalis or one of the species of the subgenus Sorbus, with $S$. aria as the pollen donor. These hybrids are generally triploid or tetraploid, and most of them are obligatorily or facultatively apomictic (Jankun 1993; Campbell and Dickinson 1990; Nelson-Jones et al. 2002).

In Western Carpathians, several Sorbus microspecies have recently been described, among which six have pink or pink-bordered petals, indicating that S. chamaemespilus (the sole rosy-flowered Sorbus species) is one of the paren- tal taxa. Generally, they are limited to the subalpine zone of high mountain ranges in the central part of Western Carpathians. Four taxa occur in relic dwarf pine stands of the Velká Fatra Mts. in central Slovakia. Based on morphology, Bernátová and Májovský (2003) suggested the origin from the hybridization of $S$. chamaemespilus and $S$. aria in the case of two taxa: $S$. zuzanae Bernátová et Májovský and S. haljamovae Bernátová et Májovský, whereas in the cases of $S$. montisalpae Bernátová et Májovský and S. atrimontis Bernátová et Májovský, they suppose that these taxa have originated from a complex hybridization process involving subgenera Sorbus, Aria and Chamaemespilus. Although the authors of the description did not explore the reproduction system of this taxon in detail, they suggested that it spreads clonally.

The mode of reproduction is reflected in spatial distribution. As documented by theoretical models, computer simulations and empirical studies, the mechanisms of pollen flow, embryo formation, seed dispersal and vegetative spread affect spatial patterns of the distribution of individuals, distribution of offsprings in relation to the parents, and consequently also spatial genetic structures (Berg and Hamrick 1994; Burczyk et al. 1996; Hardy and Vekemans 1999; Shimatani 2004). Naturally, dispersal-based spatial patterns are subsequently modified by the influences of abiotic environ- 
ment and biotic interactions, including intraspecific interactions among different age classes (Caspersen and Saprunoff 2005; LePage et al. 2000; Dovčiak et al. 2008).

The objective of this study was to identify spatial distribution patterns in subalpine Sorbus taxa and to make inference on the reproduction system of the respective taxon based on spatial patterns and genetic variation of the respective taxon.

\section{MATERIALS AND METHODS}

All investigations were performed in the National Nature Reserve Skalná Alpa in central Slovakia. The reserve, covering 524 hectares, extends over several vegetation zones from 940 to $1463 \mathrm{~m}$ a.s.l. Plant communities in the summit part, growing on Triassic dolomites, belong to ass. Adenostylo-Pinetum mughii and are formed mainly by shrubs of mountain dwarf pine and rowan with scattered Norway spruce. In addition to $S$. aucuparia, six Sorbus taxa have been found here dispersed in dwarf pine stands, namely $S$. chamaemespilus, S. aria, S. zuzanae, S. haljamovae, S. montisalpae and S. atrimontis (Bernátová and Májovský 2003).

All shrubs of Sorbus chamaemespilus and putative hybrids were mapped within a $70 \times 50 \mathrm{~m}$ rectangular area around the summit of Skalná Alpa (longer side oriented along the crest). One $S$. aria, 30 adult $S$. chamaemespilus, 35 juvenile $S$. chamaemespilus, $10 \mathrm{~S}$. haljamovae, $19 \mathrm{~S}$. zuzanae, $4 \mathrm{~S}$. montisalpae and 35 juvenile hybrid individuals (which could not be classified to taxa without ambiguity) were found on the mapped area. Positions of individuals (estimated as the center of the respective rooting area of the shrub) were measured using the Trimble GeoXT geographic positioning system with the precision of $\pm 0.3 \mathrm{~m}$, supplemented by tape measurements. As hybrids form large shrubs with asymmetric crowns, the position of an individual need not be identical with the centre of the crown projection. Polycormons were recognized as discrete individuals if there was no visible connection (e.g., through layered branch) with another individual.

Leaves were collected from a subset of flowering (unambiguously identified) Sorbus shrubs in June 2006. In total, 1 S. aria, 29 S. chamaemespilus, and 18 hybrids (4 S. haljamovae, 11 S. zuzanae and 3 S. montisalpae) were sampled. Leaves were placed in Ziploc bags with silica gel and stored at room temperature. To extract genomic DNA, two leaf discs in diameter of $8 \mathrm{~mm}$ were cut and ground to a fine powder in a mixer mill using tungsted beads. Genomic DNA was extracted using the CTAB method according to Doyle and Doyle (1987), which was modified for a smaller amount of starting material. For genotyping, microsatellite markers MSS1, MSS3, MSS4 and MSS10 according to Oddou-Muratorio et al. (2001) were used. The choice of markers was based on a preliminary study with $S$. aria $\times S$. chamaemespilus hybrids (unpublished data). All PCRs were performed in a MJ Reasearch PTC 200 or Perkin Elmer GeneAmp 9700 thermal cycler in $15 \mu$ reactions containing approximately $20 \mathrm{ng}$ of DNA, $0.45 \mathrm{U}$ of Taq polymerase (Genecraft), $4.8 \mu \mathrm{g}$ BSA, $0.2 \mu \mathrm{M}$ of forward and reverse primer, $200 \mu \mathrm{M}$ of each nucleotide, $10 \mathrm{mM}$ Tris- $\mathrm{HCl}$ $\mathrm{pH} 8.8,50 \mathrm{mM} \mathrm{KCl}, 0.1 \%$ Triton $^{\circledR} \mathrm{X}-100$ with the final concentration of $\mathrm{MgCl}_{2} 1.5 \mathrm{mM}$. Amplification profile consisted of an initial denaturation step at $95^{\circ} \mathrm{C}$ for $5 \mathrm{~min}$ followed by 35 amplification cycles (denaturation $45 \mathrm{~s}$ at $95^{\circ} \mathrm{C}$, annealing $45 \mathrm{~s}$ at $55^{\circ} \mathrm{C}$, extension $60 \mathrm{~s}$ at $72^{\circ} \mathrm{C}$ ) and a final extension step for $5 \mathrm{~min}$ at $72^{\circ} \mathrm{C}$. Before loading amplification products were diluted with the equal amount of loading dye consisting of $0.5 \%$ bromophenol blue, 8 $\mathrm{M}$ urea and $10 \mathrm{mM}$ sodium hydroxide and denatured at $95^{\circ} \mathrm{C}$ for 3 minutes and placed on ice immediately. Samples were loaded on $6 \%$ polyacrylamide sequencing gels, run at constant power $40 \mathrm{~W}$ for about 5 hours and bands were visualised by silver staning (Bassam et al. 1991). After fixing, gels were kept at $4{ }^{\circ} \mathrm{C}$ overnight, and then air dried and scanned.

Spatial analyses were performed separately for S. chamaemespilus and jointly for all hybrid taxa. Spatial distribution patterns were analyzed using the Ripley's $K$-function:

$K(t)=n^{-2} A \Sigma_{i} \Sigma_{i \neq j} w_{i j}^{-1} I_{t}\left(u_{i j}\right)$,

where $t$ is the distance for which $K$ is calculated, $n$ is the number of Sorbus individuals in the analyzed plot, $A$ is the area of the plot, $u_{i j}$ is the distance between the individuals $i$ and $j, I_{t}\left(u_{i j}\right)$ is a counter variable $\left(I_{t}\right.$ is 1 if $u_{i j}<t$ and 0 otherwise), and $w_{i j}$ is a weighting factor for edge correction (Ripley 1976; Haase 1995). In the case of a random Poisson distribution of individuals, the expected value of $K(t)=$ $\pi t^{2}$. The results are reported as the variance-stabilizing square-root transformation of $K(t)$ as:

$L(t)=\sqrt{\mathrm{K}_{t} / \pi-t}$,

where $L(t)$ equals zero when the dispersion pattern is random at the scale of the radial distance $t$, and $L(t)>0$ indicates aggregation, whereas $L(t)<0$ indicates a uniform pattern.

In the bivariate case (comparison adults vs. juveniles), the formula for the $K$-function becomes:

$K_{12}(t)=n_{1} n_{2}^{-1} A \Sigma_{i} \Sigma_{j} w_{i j}^{-1} I_{t}\left(u_{i j}\right) ; i \neq j$,

$n_{1}$ being the number of adults, $n_{2}$ the number of juveniles, and $u_{i j}$ the length of the vector from the $i$ th adult individual to the $j$ th juvenile.

To account for potential anisotropies in the distribution of juveniles around the adults because of slope effect, we also performed bivariate analysis considering the cardinal direction for individuals growing at the NW-facing (steep) slope:

$K_{\mathrm{q} 12}(t)=n_{1} n_{2}^{-1} A \Sigma_{i} \Sigma_{j} w_{i j}^{-1} I_{t(\mathrm{q})}\left(u_{i j}\right) ; i \neq j$,

where $K_{\mathrm{q} 12}(t)$ is the $K$-function value for the respective cardinal direction (defined as the direction of quadrant axes of circles centered at the adults, whereby in our case, the axes were oriented parallel and/or perpendicular to contour lines) and $I_{t(\mathrm{q})}\left(u_{i j}\right)$ is the counter variable for the respective quadrant $\left(I_{t(\mathrm{q})}\left(u_{i j}\right)=1\right.$ if $u_{i j}<t$ and the juvenile lies in the respective quadrant and $I_{t(\mathrm{q})}\left(u_{i j}\right)=0$ otherwise). The $L(t)$ statistics is then calculated as:

$L_{t}=\sqrt{4 \mathrm{~K}_{t} / \pi-t}$

(Haase 2001). To test the significance of $L_{t}$, we generated the $95 \%$ confidence intervals for the $L_{t}$ expected under 
random distribution at each $t$ from 9999 Monte Carlo simulations of randomly distributed individuals using the program SPPA version 2.0.3 (Haase 2001). Prior to the analysis, the coordinates were rotated such that only the area covered by Sorbus shrubs was excised from the whole square study plot (see Fig. 1). The omnidirectional analyses were performed for maximum $t=20 \mathrm{~m}$, i.e. half the length of the shorter side of the study plot (Peterson and Squiers 1995). Because the northwestern slope is narrower than the whole study area, the analyses considering cardinal direction were performed only for maximum $t$ of 7 and $10 \mathrm{~m}$ for $S$. chamaemespilus and hybrid taxa, respectively. The overall significance of the deviation from complete spatial randomness was tested using the Cramer-von Mises test (Haase 2001), while the distribution of the $L$-statistics was again derived from 9999 randomizations.

\section{RESULTS AND DISCUSSION}

\section{Spatial distribution}

The distribution of shrubs of S. chamaemespilus and putative hybrid taxa, as shown in Figure 1, indicates that both groups grow on both slopes along the mountain crest, but relatively few individuals can be found on the crest itself. Near the summit (triangulation point), the crest is not overgrown by mountain dwarf pine shrubs but is covered by herbaceous vegetation with the predominance of grasses. In some parts, the soil at the crest is extremely shallow and prone to drying-off, in contrast to rather deep and humusrich soil mainly on the steep eastern slope. Probably such conditions are not favourable for seed germination or seedling establishment of both groups.

Only one $S$. aria tree was found in the summit part of the reserve, but several whitebeams were found in the forest zone at a lower altitude.

In spite of very different shrub size and eventual differences in dispersal mechanisms, both groups showed quite similar omnidirectional spatial distribution patterns. Among hybrids, the adults exhibit highly significant spatial clustering up to the distance of approx. $15 \mathrm{~m}$ (Fig. 2a). Mo- reover, juvenile individuals also significantly tend to be distributed around the adults up to the distances of approx. $12 \mathrm{~m}$. However, at shortest distances $(\leq 2 \mathrm{~m})$, spatial clustering of juveniles is non-significant (Fig. 2b). We were not able to identify any clear slope effect. Distribution patterns in the upslope and downslope direction are rather similar. There seems to be a repulsion at the shortest distance $(<1$ $\mathrm{m}$ and $<2 \mathrm{~m}$ in the upslope and downslope direction, respectively, see Fig. 2c, d). At the distances over 4 m, juveniles are significantly clustered around the adults in both directions.

In S. chamaemespilus, the adults exhibit almost the same spatial pattern as the hybrid adults - a highly significant clustering at the distances $<14 \mathrm{~m}$. Again, the omnidirectional distogram of the Ripley's function suggests clustering of juveniles around the adults up to $14 \mathrm{~m}$ (Fig. 3a, b). However, bivariate Ripley's statistics considering cardinal direction showed a completely different pattern. Instead of repulsion, there seems to be clustering of juveniles in the close neighbourhood of the adults $(<2 \mathrm{~m}$ upslope and $<1$ $\mathrm{m}$ downslope). Nevertheless, overall tests are non-significant, so that there is no reliable indication of a non-random spatial pattern.

We suppose that omnidirectional patterns reflect primarily the distribution of sites appropriate for establishing, survival and growth of both groups. S. chamaemespilus and the putative hybrid taxa generally occur at high altitudes admixed in stands of mountain dwarf pine (Schaminee et al. 1992; Bernátová and Májovský 2003; Šibík et al. 2005; Erschbamer and Wallnöfer 2007). Low population densities of both groups compared to Pinus mugo indicate a lower competition ability. Juvenile Sorbus individuals are mostly distributed at crown perimeters of dwarf pine or in open patches, rather than near the shrub centres or in dense dwarf pine patches (personal observation). Both groups also avoid large open areas with grassland vegetation. Their spatial distribution seems thus to be determined by the distribution of locations and sizes of appropriate sites. The similarity of the distograms of both univariate and bivariate Ripley's function in both cases, as well as the outcomes of bivariate analysis relating hybrid taxa and S. chamaemespi-

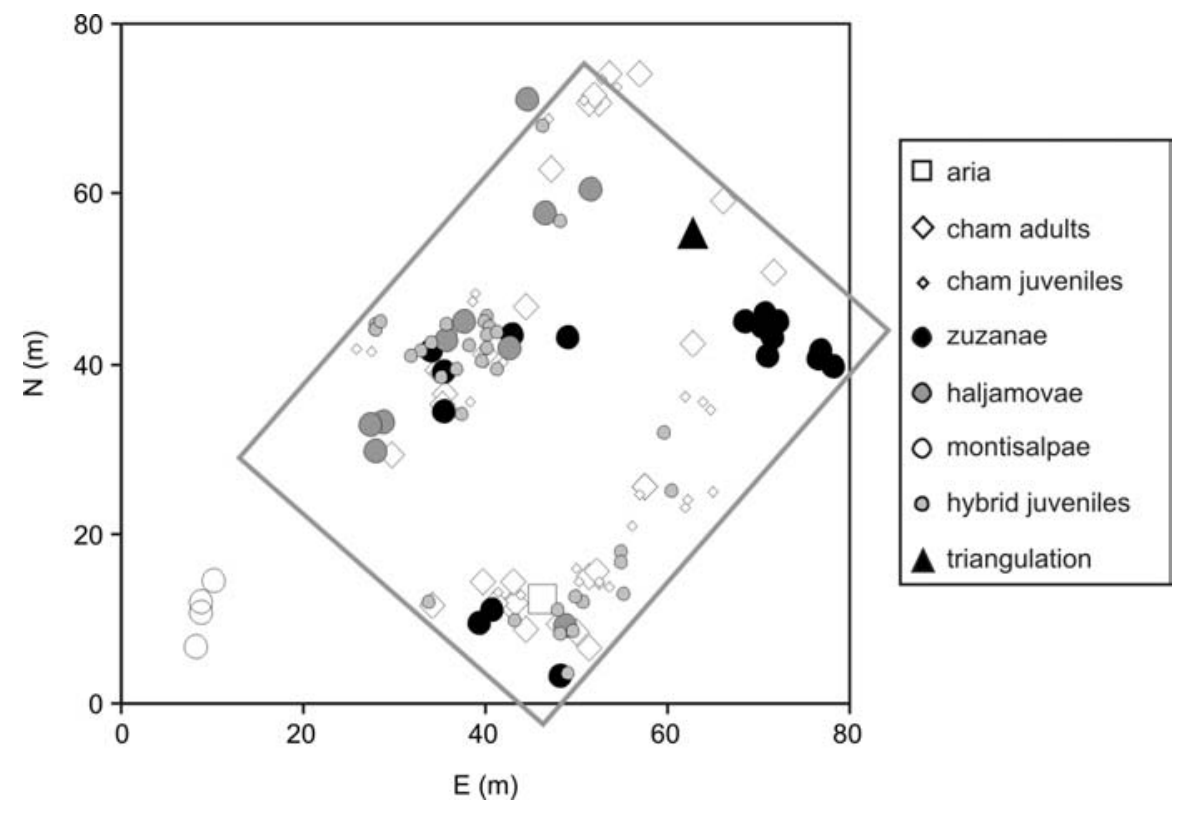

Fig. 1. Distribution of Sorbus aria, S. chamaemespilus (cham) and hybrid (S. zuzanae, S. haljamovae and $S$. montisalpae) shrubs within the mapped area of the reserve Skalná Alpa. Juvenile hybrid individuals were not taxonomically determined. The triangle shows the position of the state triangulation point at the summit. Grey line - border of the area used for spatial analyses. 
a) adults

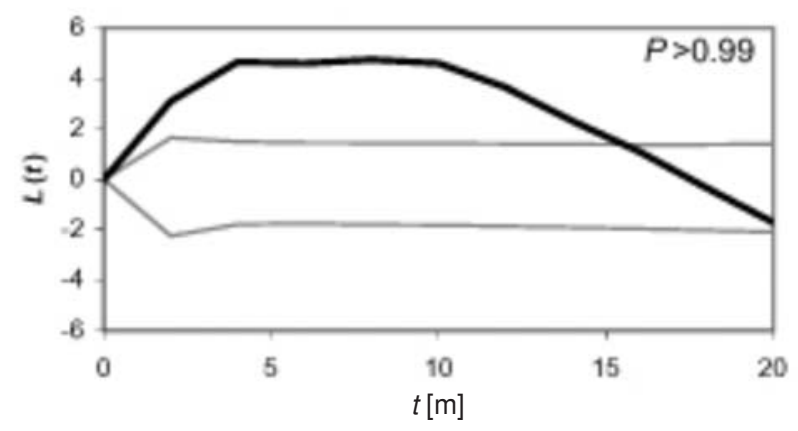

b) adults vs. juveniles omnidirectional

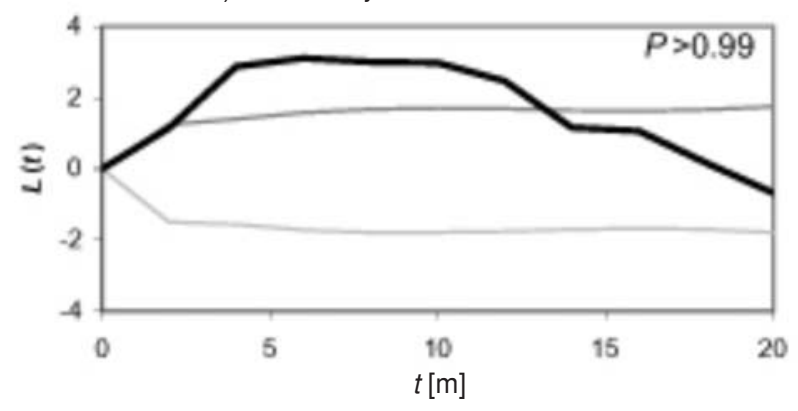

c) upslope

d) downslope

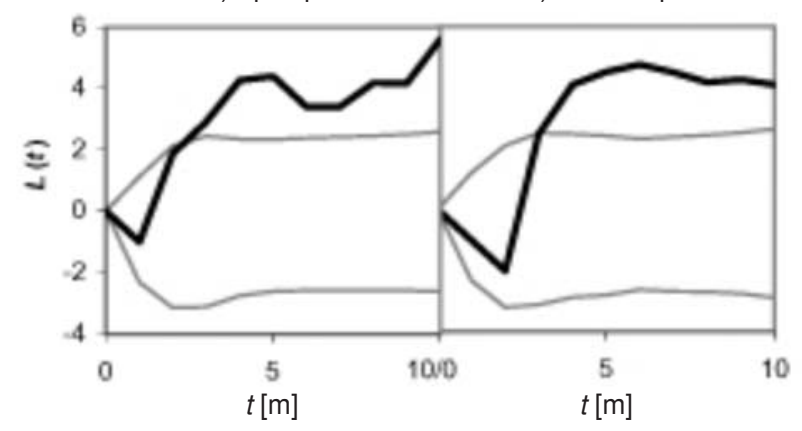

Fig. 2. Ripley's $L$-statistics describing spatial distribution patterns of hybrid Sorbus taxa. Thick black line - Ripley's $L$, thin grey line $-95 \%$ confidence envelope; a) univariate point pattern of adult (flowering) shrubs; b) bivariate omnidirectional point pattern of adults vs. juvenile (non-flowering) shrubs; c) bivariate directional point pattern of adults vs. juveniles on the north-facing slope (upslope direction); d) bivariate directional point pattern of adults vs. juveniles on the north-facing slope (downslope direction).

lus (Fig. 4) showing a strong affinity between groups suggest that they have very similar ecological requirements, corroborating previous findings of Bernátová and Májovský (2003).

Directional patterns within a relatively narrow strip on the steep eastern slope are supposed to depend mainly on dispersal mechanisms and intraspecific biotic interactions. In addition to seeds, subalpine Sorbus species are known to propagate by layering of branches (Kociánová et al. 2005). Propagation by root suckers is common in Sorbus (S. latifolia - Rudow and Aas 1997; S. torminalis - DemesureMusch and Oddou-Muratorio 2003; S. domestica - Rotach 2003). It has not been documented in S. chamaemespilus or its hybrids, but cannot be excluded.

There is no reliable indication about the increased occurrence of juveniles in the immediate neighbourhood of a) adults

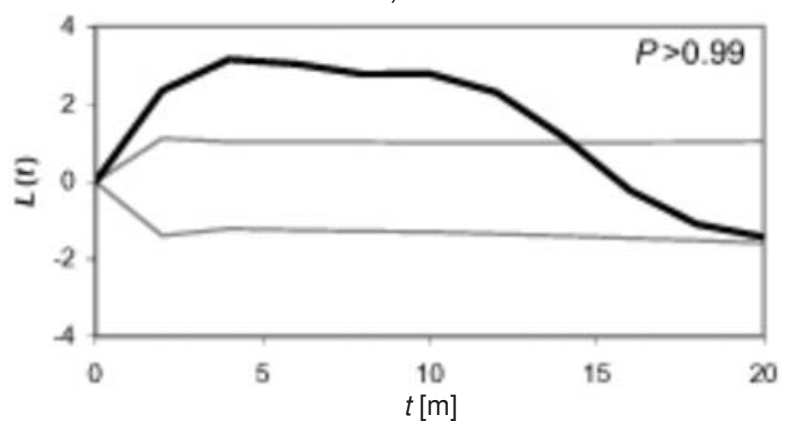

b) adults vs. juveniles omnidirectional

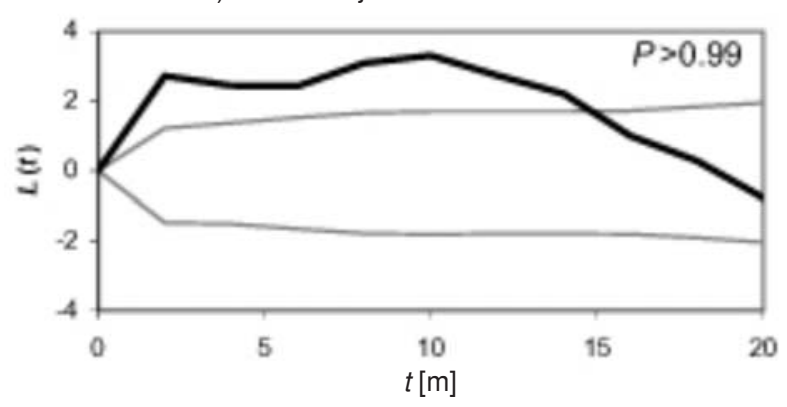

c) upslope

d) downslope

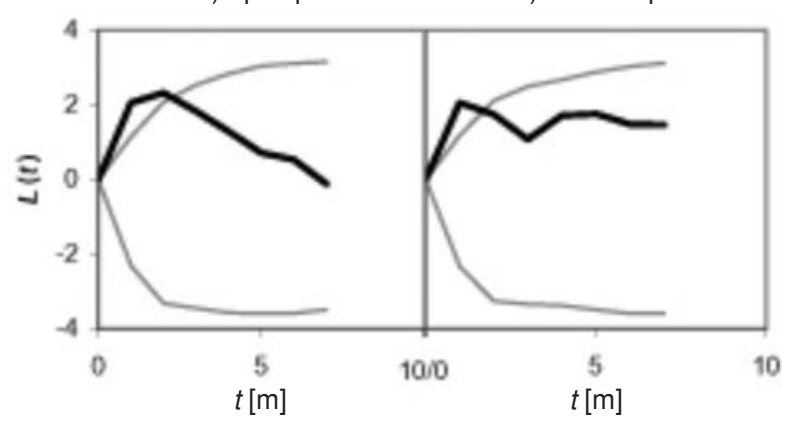

Fig. 3. Ripley's $L$-statistics describing spatial distribution patterns of Sorbus chamaemespilus. Thick black line - Ripley's L, thin grey line - 95\% confidence envelope; a) univariate point pattern of adult (flowering) shrubs; b) bivariate omnidirectional point pattern of adults vs. juvenile (non-flowering) shrubs; c) bivariate directional point pattern of adults vs. juveniles on the north-facing slope (upslope direction); d) bivariate directional point pattern of adults vs. juveniles on the north-facing slope (downslope direction).

adults in S. chamaemespilus. This indicates that for this species, availability of favourable sites is more limiting for plant establishment than spreading ability, either through seeds or through vegetative propagation, at least at this particular site. Another explanation (which, however, cannot be explicitly tested on the basis of our material) is that seed dispersal mechanisms are distance-independent at the spatial scale concerned. In Sorbus, passage of seeds through bird guts is known to improve substantially seed germination (Paulsen and Hogstedt 2002; Paulsen et al. 2006). Seeds digested and dispersed by birds may thus play a more important role in seedling establishment than gravity-dispersed seeds in the neighbourhood of maternal plants.

Absence of adult-juvenile clustering and even an indication for repulsion at short distances in hybrid taxa results from intraspecific competition. The shade under dense 


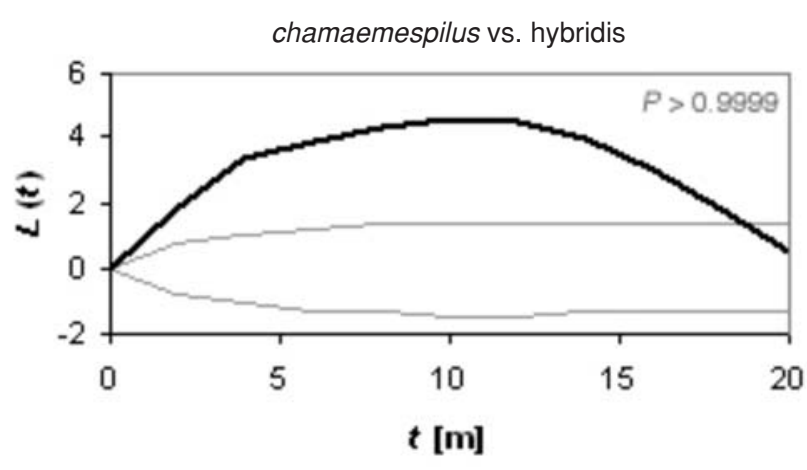

Fig. 4. Ripley's $L$-statistics describing bivariate omnidirectional spatial pattern of adult shrubs of Sorbus chamaemespilus vs. hybrid taxa. Thick black line - Ripley's $L$, thin grey line - $95 \%$ confidence envelope.

crowns does not allow seedling survival and apparently hampers even establishment of vegetative offsprings. A larger reach of this effect in the downslope direction is caused by strongly eccentric crowns, which are generally extended downslope due to snow pressure, and (eventually) by asymmetric root systems. This effect is non-significant, but we suppose that this is only due to small sample sizes in both age classes, given by the size of the mapped area. At distances over $4 \mathrm{~m}$, there is a highly significant affinity between juveniles and adults, reflecting probably spatially limited spread. All three recorded hybrid taxa form much larger shrubs producing incomparably more seeds than S. chamaemespilus. The density of seeds dispersed near the crown perimeters is then sufficient to result in higher density of juveniles in the vicinity of adults despite a lower germination rate compared to seed dispersed by birds at larger distances. In large and dense polycormons, there are also more branches trailing near the soil surface and thus more opportunities for branch layering than in $S$. chamaemespilus. Finally, facilitative interactions between generations, related to the modification of environment rather than to dispersal, cannot be excluded. Nurse-plant effects have been documented in many plant species (cf. Bertness and Callway 1994; Lortie et al. 2004). However, we cannot test this hypothesis explicitly.

Genetic variation and implications for reproduction system

S. chamaemespilus is generally considered a sexually reproducing species (Aldasoro et al. 1998), although triploid

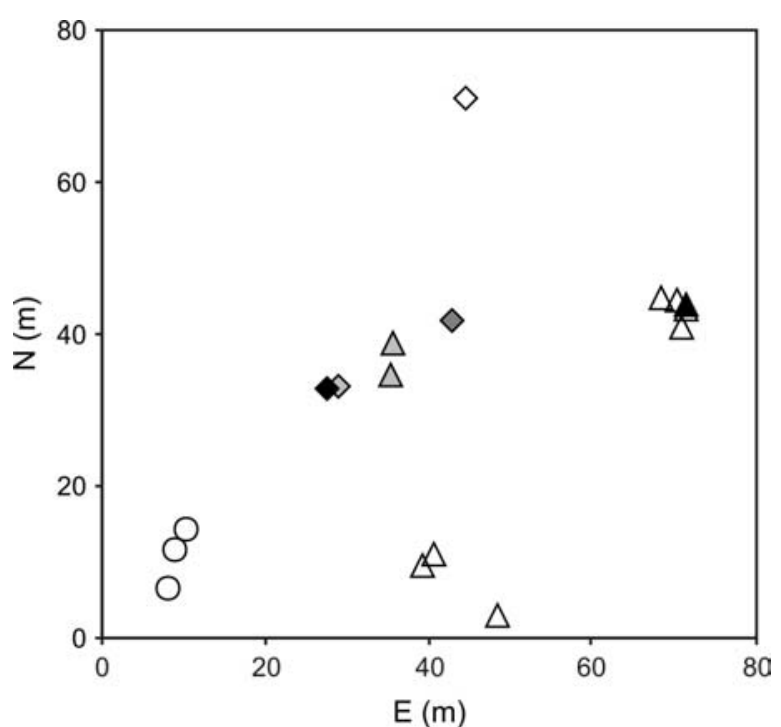

Fig. 6. Spatial distribution of SSR phenotypes among the adult shrubs of putative hybrid Sorbus taxa in the Skalná Alpa reserve. Diamonds $-S$. haljamovae, circles - S. montisalpae, triangles - S. zuzanae.

(thus presumably apomictic) individuals were also found. In contrast, most intermediate taxa are supposed to be allopolyploids and generally agamospermous (Nelson-Jones et al. 2002). Therefore, we expected to find genotypic variation in S. chamaemespilus and absence of variation in hybrids. The outcome of microsatellite analysis was just opposite: two microsatellite loci (MSS1 and MSS3) were monomorphic in all samples, the loci MSS4 and MSS10 were monomorphic in S. chamaemespilus but 8 different phenotypes were found in the hybrid group (as we have no reliable information about the ploidy level, were did not attempt to interpret SSR banding patterns genetically). In $S$. haljamovae, each individual even possessed a unique genotype. For illustration see Figure 5, showing one of the SSR markers (MSS10). Although sample size is too small for a quantitative evaluation of spatial genetic structures, genotypes of the hybrids are apparently spatially clustered (Fig. 6), suggesting clonal spread.

There are several possible explanations for the existence of genetic variation within supposedly apomictic hybrid taxa:

- The taxa are sexual in spite of supposed polyploidy, and the variation is produced through segregation and re-

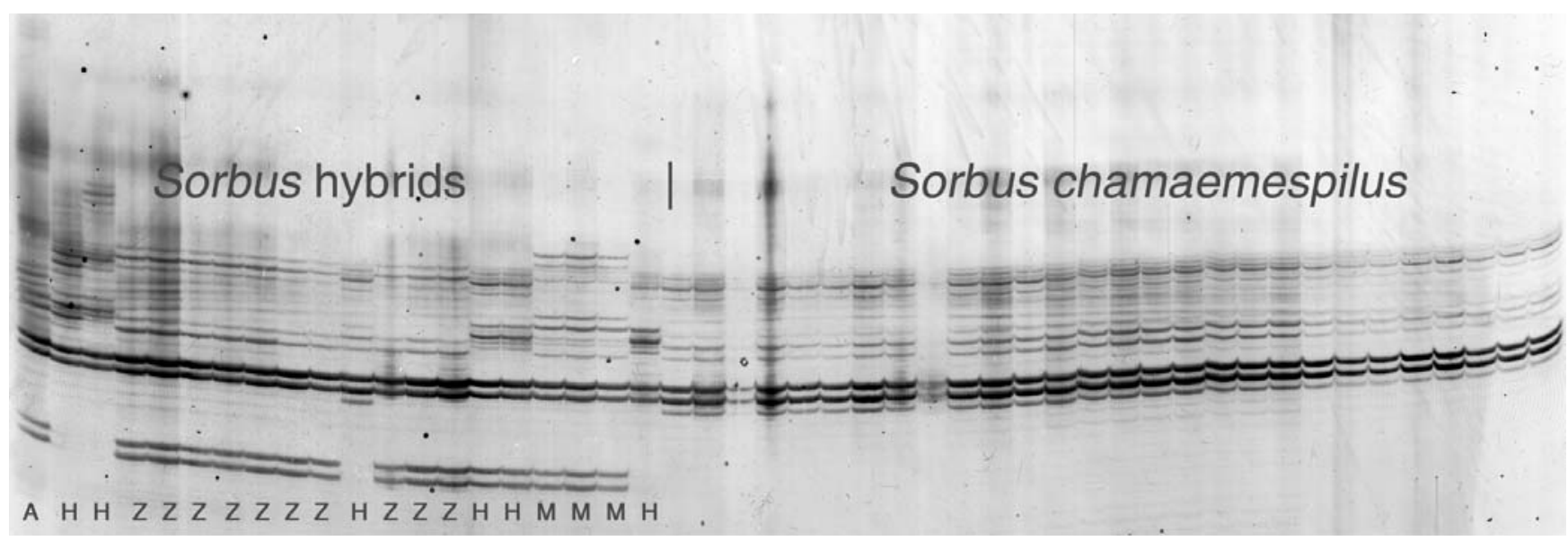

Fig. 5. Microsatellite phenotypes in Sorbus chamaemespilus and hybrid Sorbus taxa as revealed using the MSS10 marker. Designation of taxa: H - S. haljamovae, M - S. montisalpae, Z - S. zuzanae, A - S. aria. 
combination. Although polyploidy frequently leads to problems during the meiosis because of the formation of univalents and multivalents in the pachytene, allotetraploids generally behave like functional diploids (Walters and Briggs 1984). Such fertile allopolyploids may arise either through fertilization of unreduced gametes or polyploidization of sterile diploid hybrids (Campbell et al. 1991; Walters and Briggs 1984).

- The taxa are apomictic and the variation has been formed through accumulated mutations (Aldasoro et al. 1998; Campbell and Dickinson 1990). In microsatellite loci, representing non-coding regions of DNA, new variants are easily produced by the slippage of DNA polymerase during DNA replication, and have a higher probability to be preserved in the gene pool, because they are selectively neutral (Vendramin and Hansson 2006). Most "alleles" within a population are expected to differ in one or few repetitions of the microsatellite motif. This is not the case of the investigated SSR loci in Sorbus hybrids, where no continuity in the distribution of allele sizes was observed (pers. observation).

- Recurrent allopolyploid hybridization. This mechanism requires high production of unreduced gametes in both parental species, which is not uncommon in plants. E.g., Ramsey (2007) found that between one third and one half of Achillea borealis plats produced unreduced gametes, whereby the highest unreduced pollen frequency reached as much as $16 \%$. However, such a high production of unreduced gametes in diploid sexual Sorbus species has not been documented. Moreover, all hybrid taxa occur at several locations in the Velka Fatra Mts., mostly in mixed stands. It seems improbable that several hybridization events would produce morphologically homogeneous offsprings.

- Recurrent hybridization leading to the formation of diploid hybrids, which are expected to be sterile because of the lack of homology of chromosomes. Again, multiple hybridization events are required to produce variation. However, rosy-flowered Sorbus hybrids are generally tetraploid (Jankun 1993; Jankun and Kovanda 1986), so that this hypothesis is improbable.

The last two hypotheses allow a quite recent origin of the hybrid taxa, but require permanent presence of parental species on the site or in its close neighbourhood. General$1 \mathrm{y}$, it is $S$. aria which is considered to be the mediator of hybridization in Sorbus (Aldasoro et al. 1998; Nelson-Jones et al. 2002). However, only one flowering tree was found within the mapped area and a cursory inspection of dwarf pine stands in the summit area of Skalná Alpa revealed only one further individual of this species. Also the density of $S$. aria in the surrounding forests is quite low. Moreover, a complete genetic homogeneity of $S$. chamaemespilus in the mapped area at SSR loci indicates that this species may reproduce apomictically at this locality. Actually, although many individuals were flowering and produced fruits containing germinating seeds, flowers were closed during the whole day (observations were made several times during three flowering seasons). It is thus questionable whether the pollen exchange within broad area around the reserve is intense enough to allow recurrent formation of such complex hybrids.

In contrast, the first two hypotheses assume a single hybridization ("founding") event, but require a longer persi- stence of the population. Such assumption is not excluded in the case of hybrid taxa. Their occurrence is restricted to very specific sites, namely Pinus mugo stands on limestones and dolomites (Bernátová and Májovský 2003). Although the highest parts of the Velka Fatra Mts. were mostly deforested during the 16th and 17 th centuries to acquire pastures for sheep, several relic dwarf pine islands have been preserved, which may have provided refuges for Sorbus hybrids.

\section{Conservation implications}

The opinions about the taxonomic value of polyploid, frequently apomictic taxa are diverging. Dickinson and Campbell (1991), using just the example of Sorbus taxa, warn against precocious description of new species without the knowledge of their genetic variation and reproduction system, as such approach frequently leads to the recognition of single genotypes as species. In contrast, Soltis et al. (2007) support recognizing such species arguing that different cytotypes are largely reproductively isolated and thus represent different biological units, fulfilling the requirements of several species concepts.

In Central Europe, there is a general tendency towards legal protection of rare plant species under nature conservation schemes, and newly described rare species are frequently rapidly inserted into red lists. Such approach has been challenged by Pillon and Chase (2007), who argued that the recognition of numerous and poorly circumscribed taxa represents an obstacle to their conservation because rare, poorly defined species may receive higher priority for conservation than taxonomically good species. Courchamp et al. (2006) even suggested that the exaggerated value placed on rarity causes overexploitation of rare species and may ultimately drive them to extinction. For sure, this is a problem of herbs (such as orchids) rather than shrubs and trees. Nevertheless, too long lists of protected species are negatively apprehended by the public, so that extending them by the inclusion of new taxa may become contraproductive. To our opinion, in the case of hybrid subalpine Sorbus taxa in central European mountains, the appropriate conservation method is strongly associated with the phylogenetic origin and the reproduction system. If a particular taxon originated from a single event and succeeded to establish, then the legal protection is an appropriate way of conservation. The existence of the intra-taxon genetic variation is an indication that the taxon is not a transitory biological unit which arose and will soon disappear, so that it is a factor increasing the conservation value. On the other hand, if a taxon originated from recurrent processes such as recurrent hybridization, then the conservation of sites and processes leading to the formation of hybrids is more important and more efficient than the conservation of the products of hybridization themselves. A more profound knowledge of the phylogeny and reproduction system of endemic species is thus indispensable for correct decision about their management. Sorbus taxa may serve as a good model example for this purpose.

\section{ACKNOWLEDGMENTS}

Thanks are due to Dr. Dana Bernátová for taxonomical determination of samples. This study was supported by the grant no. 1/3262/06 of the Slovak Grant Agency for Science (VEGA). 


\section{LITERATURE CITED}

ALDASORO J.J., AEDO C., NAVARRO C., GARMENDIA F.M. 1998. The genus Sorbus (Maloideae, Rosaceae) in Europe and in North Africa: Morphological analysis and systematics. Syst. Bot. 23 (2): 189-212.

BASSAM B.J., CAETANO-ANNOLÉS G., GRESHOFF P.M. 1991. Fast and sensitive silver staining of DNA in polyacrylamide gels. Anal. Biochem. 196: 80-83.

BERG E.E., HAMRICK J.L. 1995. Fine-scale genetic structure of a Turkey oak forest. Evolution 49: 110-120.

BERNÁTOVÁ D., MÁJOVSKÝ J. 2003. New endemic hybridogeneous species of the genus Sorbus in the Western Carpathians. Biologia 58 (4): 781-790.

BERTNESS M.D., CALLWAY R. 1994. Positive interactions in communities. Trends Ecol. Evol. 9: 191-193.

BURCZYK J., ADAMS W.T., SHIMIZU J.Y. 1996. Mating patterns and pollen dispersal in a natural knobcone pine (Pinus attenuata Lemmon) stand. Heredity 77: 251-260.

CAMPBELL C.S., DICKINSON T.A. 1990. Apomixis, patterns of morphological variation, and species concepts in subfam. Maloideae (Rosaceae). Syst. Bot. 15: 124-135.

CAMPBELL C.S., GREENE C.W., DICKINSON T.A. 1991. Reproductive biology in subfam Maloideae (Rosaceae). Syst. Bot. 16 (2): 333-349.

CASPERSEN J.P., SAPRUNOFF M. 2005. Seedling recruitment in a northern temperate forest: the relative importance of supply and establishment limitation. Can. J. For. Res. 35: 978-989.

COURCHAMP F., ANGULO E., RIVALAN P., HALL R.J., SIGNORET L., BULL L., MEINARD Y. 2006. Rarity value and species extinction: The anthropogenic Allee effect. Plos Biol. 4 (12): 2405-2410.

DEMESURE-MUSCH B., ODDOU-MURATORIO S. 2004. EUFORGEN Technical Guidelines for genetic conservation and use for wild service tree (Sorbus torminalis). IPGRI, Rome, 6 pp.

DICKINSON T.A., CAMPBELL C.S. 1991. Population structure and reproductive ecology in the Maloideae (Rosaceae). Syst. Bot. 16(2): 350-362.

DOVČIAK M., HRIVNÁK R., UJHÁZY K., GÖMÖRY D. 2008. Seed rain and environmental controls on invasion of $P i$ cea abies into grassland. Plant Ecol. 194: 135-148.

DOYLE J.J., DOYLE J.L. 1987. A rapid DNA isolation procedure for small quantities of fresh leaf tissue. Phytochem. Bull. 19: 11-15.

ERSCHBAMER B., WALLNÖFER S. 2007. Vegetation at the Upper Timberline. In: Trees at their upper limit. Treelife limitation at the Alpine timberline. Gerhard Wieser and Michael Tausz (eds). Springer, p. 67-78.

HAASE P. 1995. Spatial pattern analysis in ecology based on Ripley's $K$-function: Introduction and methods of edge correction. J. Veg. Sci. 6: 572-582.

HAASE P. 2001. Can isotropy vs anisotropy in the spatial association of plant species reveal physical vs abiotic facilitation? J. Veg. Sci. 12: 127-136.

HARDY O.J., VEKEMANS X. 1999. Isolation by distance in a continuous population: reconciliation between spatial autocorrelation analysis and population genetics models. Heredity 83: $145-154$.

JANKUN A. 1993. Evolutionary significance of apomixis in the genus Sorbus (Rosaceae). Fragm. Flor. Geobot. 38: 627-686.

JANKUN A., KOVANDA M. 1986. Apomixis in Sorbus sudetica. Embryological studies in Sorbus L. Preslia 58: 7-19.

KOCIÁNOVÁ M., ŠTURSOVÁ H., ZAHRADNÍKOVÁ J. 2005. Klonální růst endemického jeřábu Sorbus sudetica v Krkonoších. Opera Corcontica 42: 99-105 (in Czech).
LE PAGE P.T., CANHAM C.D., COATES K.D., BARTEMUCCI P. 2000. Seed abundance versus substrate limitation of seedling recruitment in northern temperate forests of British Columbia. Can. J. For. Res. 30:415-427.

LORTIE C.J., BROOKER R.W., CHOLER P., KIKVIDZE Z., MICHALET R., PUGNAIRE F.I., CALLAWAY R.M. 2004. Rethinking plant community theory. Oikos 107 (2): 433-438.

NELSON-JONES E.B., BRIGGS D., SMITH A.G. 2002. The origin of intermediate species of the genus Sorbus. Theor. Appl. Genet. 105 (6-7): 953-963.

ODDOU-MURATORIO S., ALIGON C., DECROOCQ S., PLOMION C., LAMANT T., MUSCH-DEMESURE B. 2001: Microsatellite primers for Sorbus torminalis and related species. Molec. Ecol. Notes 1: 297-299.

PAULSEN T.R., HOGSTEDT G. 2002. Passage through bird guts increases germination rate and seedling growth in Sorbus aucuparia. Funct. Ecol. 16 (5): 608-616.

PAULSEN T.R., LINDTJORN O., GJERDET N.R., HOGSTEDT G. 2006. Avian gut passage reduces seed exit costs in Sorbus aucuparia (Rosaceae) as measured by a diametral compression test. Funct. Plant Biol. 33 (4): 401-406.

PETERSON C.J., SQUIERS E.R. 1995. An unexpected change in spatial pattern across 10 years in an aspen white-pine forest. J. Ecol. 83 (5): 847-855.

PILLON Y., CHASE M.W. 2007. Taxonomic exaggeration and its effects on orchid conservation. Conserv. Biol. 21 (1): 263-265 .

RAMSEY J. 2007. Unreduced gametes and neopolyploids in natural populations of Achillea borealis (Asteraceae). Heredity 98 (3): 143-150.

RIPLEY B.D. 1976. The second-order analysis of stationary processes. J. Appl. Proba. 13: 255-266.

ROTACH P. 2003. EUFORGEN Technical Guidelines for genetic conservation and use for service tree (Sorbus domestica). IPGRI, Rome, 6 pp.

RUDOW A., AAS G. 1997. Sorbus latifolia sl in Central Northern Switzerland: Distribution, site and population biology. Bot. Helvet. 107 (1): 51-73.

SCHAMINEE J.H.J., JANSEN J., HENNEKENS S.M. 1992. Scrub communities dominated by Sorbus species in the sub-alpine zone of the Monts-Du-Forez (Massif-Central, France). Proceedings of the Koninklijke Nederlandse Akademie van Wetenschappen - Biological Chemical Geological Physical and Medical Sciences 95 (4): 473-497.

SHIMATANI K. 2004. Spatial molecular ecological models for genotyped adults and offspring. Ecol. Modell. 174 (4): 401-410.

ŠIBÍK J., VALACHOVIČ M., KLIMENT J. 2005. Plant communities with Pinus mugo (alliance Pinion mugo) in the subalpine belt of the Western Carpathians - A numerical approach. Acta Soc. Bot. Pol. 74 (4): 329-343.

SOLTIS D.E., SOLTIS P.S., SCHEMSKE D.W., HANCOCK J.F., THOMPSON J.N., HUSBAND B.C., JUDD W.S. 2007. Autopolyploidy in angiosperms: have we grossly underestimated the number of species? Taxon 56 (1): 13-30.

VENDRAMIN G.G., HANSON O.K. 2006. Molecular markers for characterizing variation in forest trees. In: Conservation and Management of Forest Genetic Resources in Europe. T. Geburek, J. Turok (eds). Arbora Publishers, Zvolen, p. 337-368 .

WALTERS D., BRIGGS S.M. 1984. Plant Variation and Evolution. Cambridge University Press, Cambridge, 416 pp.

WARBURG E.F., KÁRPÁTI Z.E. 1968. Sorbus L. In: Flora Europaea. Tutin T.G., Heywood V.H., Burges N.A., Moore D.M., Valentine D.H., Walters S.M., Webb D.A. (eds). Cambridge University Press, Cambridge, p. 67-71. 